Massimo Fabio:

Customs Law of the European Union

Fourth Edition, Wolters Kluwer, 2012

Tom Walsh: European Union Customs Code, Wolters Kluwer 2015

Envar som forskar kring frågor om ekonomiska brott inom EU stöter för eller senare på tullbrotten. Varor förs in i något medlemsland under falsk beteckning (kollies som innehåller tobak deklareras som livsmedel) eller varor som finns i ett tullager för vidaresändning till ett icke EU-land tas olovligen från lagret och säljs på den inre marknaden. Bestraffningen av dessa och andra gärningar sker enligt den nationella straffrätten. Samtidigt måste unionens tullagstiftning beaktas vid bestämmandet av det straffrättsliga ansvaret.

EU:s tullagstiftning är mycket omfattande och direkt bindande för samtliga medlemsländer. De viktigaste bestämmelserna är EU:s tullkodex (EEG 2913/92), dess tillämpningsförordning (EEG 2454/93), förordningen om ett gemenskapssystem för tullbefrielse (tullfrihetsförordningen, EG 1186/2009) samt den s.k. TARIC-förordningen, som gäller tariffer och nomenklatur (EEG 2658/87). Som bekant får dessa förordningar inte implementeras i medlemsstaternas lagstiftning utan det är endast möjligt att i nationella tullagar inta kompletterande bestämmelser. En ny tullkodex som kallades för »Modernised customs code« (MCC) godkändes år 2008 (EG 450/2008). MCC upphävdes dock innan den hann börja tilllämpas. En ny tullkodex, dvs. »Union customs code« (UCC), utarbetades åren 2012-2013 (EU 952/2013) och förväntas träda i kraft i juni 2016. Fram till dess tillämpas den gamla tullkodexen.

För att få ett grepp om förhållandet mellan nationell straffrätt och unionens tullagstiftning är man i de flesta fall beroende av den juridiska doktrinen. De här aktuella böckerna utgör omfattande tolkningsverk om och kring unionens tullagstiftning. Fabios bok innehåller ingen löpande sidnumrering utan sidorna anges skilt för varje kapitel, vilka är sammanlagt 25 till antalet. Därtill finns två appendix fogade till boken. Den egentliga texten är ca 750 sidor. Walsh bok är betydligt mera omfattande. Den är indelad i sammanlagt 39 kapitel och omfattar strax över 1000 sidor löpande text.

Bägge verken är skrivna med utgångspunkt i gällande tullkodex jämte öviga bestämmelser. Fabio redogör också konsekvent för innehållet i den senare upphävda MCC. Walsh igen har som jämförelsematerial i första hand UCC som således borde träda i kraft i mitten av år 2016. Men även han berör MCC. Det blir 
intressant att se om UCC kan träda i kraft enligt planerna. Om så inte sker kommer Fabios och Walshs böcker att länge vara up to date.

Fabios bok har karaktären av en monografi eftersom han inte följer artikelordningen i tullkodex utan använder sig av en egen struktur. Walsh följer däremot strukturen i gällande tullkodex och utgör i den meningen en traditionell artikelkommentar. Om man vill använda Fabios bok som ett uppslagsverk gällande enskilda artiklar fungerar den inte så bra; rubrikerna på de enskilda kapitlen säger ibland men inte alltid vad de handlar om.

Bägge böcker har sina styrkor och svagheter. Fabios text är mera lästläst och innehåller inte så många interna hänvisningar till andra delar av texten. Det jag mest saknar i texten är redogörelser för rättspraxis från EU-domstolen. Nu hittas enbart en lista på relevanta domar i slutet av kapitlen. Boken innehåller tyvärr inget rättsfallsregister som skulle ha gett en överblick av de EU-domar som Fabio anser centrala. Walsh artikelkommentar är i jämförelse med Fabios bok mycket mera utförlig. Den hänvisar genomgående till andra relevanta artiklar och bestämmelser. Därtill kommer att referaten av EU-domstolens avgöranden är både omfattande och klarläggande. Ur ett straffrättsligt perspektiv är särskilt rättsfallen i anslutning till artikel 203 av största intresse. I nämnda artikel anges när varor ska anses ha avlägsnats från tullövervakningen (»customs supervision«), något som skapar en s.k. tullskuld. Vanligen är tullskatten inte särskilt betungande, något som däremot inte kan sägas om skyldigheten att betala mervärdesskatt. Åtminstone i Finland är skatteskyldigheten kopplad till uppkomsten av tullskulden.

För den som vill bekanta sig med EU:s tullagstiftning lönar det sig att börja med Fabios bok och sedan för detaljerna läsa Walshs bok. Böckerna kan med fördel läsas parallellt.

\section{Dan Frände}

Professor, Helsingfors universitet 